University of Wollongong

Research Online

Australian Institute for Innovative Materials -

Papers

Australian Institute for Innovative Materials

2013

An overview - Functional nanomaterials for lithium rechargeable batteries, supercapacitors, hydrogen storage, and fuel cells

Hua-Kun Liu

University of Wollongong, hua@uow.edu.au

Follow this and additional works at: https://ro.uow.edu.au/aiimpapers

Part of the Engineering Commons, and the Physical Sciences and Mathematics Commons

Research Online is the open access institutional repository for the University of Wollongong. For further information contact the UOW Library: research-pubs@uow.edu.au 


\title{
An overview - Functional nanomaterials for lithium rechargeable batteries, supercapacitors, hydrogen storage, and fuel cells
}

\begin{abstract}
There is tremendous worldwide interest in functional nanostructured materials, which are the advanced nanotechnology materials with internal or external dimensions on the order of nanometers. Their extremely small dimensions make these materials unique and promising for clean energy applications such as lithium ion batteries, supercapacitors, hydrogen storage, fuel cells, and other applications. This paper will highlight the development of new approaches to study the relationships between the structure and the physical, chemical, and electrochemical properties of functional nanostructured materials. The Energy Materials Research Programme at the Institute for Superconducting and Electronic Materials, the University of Wollongong, has been focused on the synthesis, characterization, and applications of functional nanomaterials, including nanoparticles, nanotubes, nanowires, nanoporous materials, and nanocomposites. The emphases are placed on advanced nanotechnology, design, and control of the composition, morphology, nanostructure, and functionality of the nanomaterials, and on the subsequent applications of these materials to areas including lithium ion batteries, supercapacitors, hydrogen storage, and fuel cells.
\end{abstract}

\section{Keywords}

rechargeable, batteries, overview, supercapacitors, functional, hydrogen, storage, fuel, cells, nanomaterials, lithium

\section{Disciplines}

Engineering | Physical Sciences and Mathematics

\section{Publication Details}

Liu, H. Kun. (2013). An overview - Functional nanomaterials for lithium rechargeable batteries, supercapacitors, hydrogen storage, and fuel cells. Materials Research Bulletin, 48 (12), 4968-4973. 


\title{
An overview - Functional nanomaterials for lithium rechargeable batteries, supercapacitors, hydrogen storage, and fuel cells
}

\author{
Hua Kun Liu* \\ Professor, \\ Institute for Superconducting and Electronic Materials \\ ARC Centre for Electromaterials Science \\ Innovation Campus, University of Wollongong \\ Squires Way, North Wollongong \\ NSW 2500 Australia \\ Email: hua@uow.edu.au \\ Phone: +61-2-4221-4547 \\ Fax: +61-2-4221-5731 \\ Web: www.isem.uow.edu.au
}

There is tremendous worldwide interest in functional nanostructured materials, which are the advanced nanotechnology materials with internal or external dimensions on the order of nanometers. Their extremely small dimensions make these materials unique and promising for clean energy applications such as lithium ion batteries, supercapacitors, hydrogen storage, fuel cells, and other applications. This paper will highlight the development of new approaches to study the relationships between the structure and the physical, chemical, and electrochemical properties of functional nanostructured materials. The Energy Materials Research Program at the Institute for Superconducting and Electronic Materials, the University of Wollongong, has been focused on the synthesis, characterization, and applications of functional nanomaterials, including nanoparticles, nanotubes, nanowires, nanoporous materials, and nanocomposites. The emphases are placed on advanced nanotechnology, design, and control of the composition, morphology, nanostructure, and functionality of 
the nanomaterials, and on the subsequent applications of these materials to areas including lithium ion batteries, supercapacitors, hydrogen storage, and fuel cells.

Keywords: functional nanostructured materials, lithium ion batteries, supercapacitors, hydrogen storage, fuel cells

\section{Introduction:}

For a clean environment, batteries (alone or in combination with supercapacitors) for electric vehicles (EVs), hybrid electric vehicles (HEVs), or large-scale hydrogen fuel cells are believed to be the key to reducing our dependence on oil. Currently, among all the different kinds of rechargeable batteries, the Li-ion batteries (LIBs) will be the best choice for powering EVs and HEVs. There are serious challenges for further development of Li rechargeable batteries for electric vehicles $^{1}$, however. The lithium ion batteries ${ }^{2-6}$ still cannot meet the required combinations of high energy density, high power, and high rate capability. Supercapacitors can be charged and discharged very quickly and are possible as an alternative power source; however, they are expensive, as they are made of expensive oxides (such as $\mathrm{RuO}_{2}$ and $\mathrm{IrO}_{2}$, which show high specific capacitance) that are only available in scarce quantities ${ }^{7}$.

Hydrogen, another energy storage alternative, may be stored as a gas, a liquid, or bonded within a solid material. The latter is the safest approach, and hydrogen storage in this form has a relatively high volumetric capacity. ${ }^{8.9}$ Up to now, however, no hydride system has been found to meet all of the demands of mobile (fuel storage, internal combustion, fuel cell) applications. Such gas-phase 
applications await novel technologies to further improve the hydrogen storage capacity and reversibility. In direct methanol fuel cells (DMFCs) or direct alcohol fuel cells (DAFCs), and the proton exchange membrane fuel cells (PEMFCs), the anodic oxidation of combustibles and the cathodic reduction of oxygen should be catalysed to occur at adequate rates at low temperatures ${ }^{10}$. To develop catalysts with high activity, reasonable reliability, and durability, in combination with cost reduction, is an important task.

\section{Applications of functional nanostructured materials:}

Functional nanomaterials are advanced nanotechnology materials with internal or external dimensions on the order of nanometers. These extremely small dimensions make these materials unique and promising for clean energy areas

such as lithium ion batteries ${ }^{11-25}$, supercapacitors ${ }^{19,}$ 26-28 , hydrogen storage ${ }^{29-30}$, fuel cells ${ }^{31-33}$, and other applications. Some examples from our recent work demonstrate that nanostructured materials can play significant role in improving the electrochemical performance of proposed alternative electrode materials.

\subsection{Functional nanostructured materials for lithium ion batteries:}

Graphite and $\mathrm{LiCoO}_{2}$ are the commercial anode and cathode materials, respectively, since the introduction of LIBs in the 1990s. There two issues for the electrode materials: (1) lithium storage capacities are still not enough for the market requirements and (2) to improve both the cycling stability and the rate capability is a great challenge. Thus much research has been focused on high 
capacity materials such as silicon (4200 mAh g ${ }^{-1}$ ), germanium (1623 mAh g $\left.{ }^{-1}\right)$, tin (993 mAh $\mathrm{g}^{-1}$ ) and transition metal oxides (100 500 $\mathrm{mAh}^{-1}$ ) to replace the graphite (372 $\mathrm{mAh} \mathrm{g}^{-1}$ ) anode, however, there is a large volume expansion and contraction problem associated with $\mathrm{Li}^{+}$insertion and removal reactions, respectively; and new cathode material $\mathrm{LiNi}_{1 / 3} \mathrm{Mn}_{1 / 3} \mathrm{Co}_{1 / 3} \mathrm{O}_{2}$ (for portable electronics due to safety and low cost), spinel $\mathrm{LiMn}_{2} \mathrm{O}_{4}$ and olivine $\mathrm{LiFePO}_{4}$ (for transportation applications due to chemical stability and high charge- discharge rate capability) are promising for replacing commercial cathode material $\mathrm{LiCoO}_{2}$.

As Si/graphene composite can accommodate large volume changes of Si and maintain good electronic contact, nano-Si/graphene composite shows enhanced electrochemical performance, with a lithium storage capacity of 1168 $\mathrm{mAh} \mathrm{g}^{-1}$ and coulombic efficiency of $93 \%$ up to 30 cycles $^{20}$.

It is interesting that a cluster-type nanostructure and a non-clustered structure (Figure 1) have different effects on the electrochemical performanceof different composites of clustered-Ge/carbon (C-Ge/C) and non-clustered$\mathrm{Ge} /$ carbon (NC-Ge/C). The NC-Ge/C structure showed very poor capacity retention at rates over $1 \mathrm{C}$, while the $\mathrm{C}-\mathrm{Ge} / \mathrm{C}$ structure showed an exceptionally high rate capability up to the $40 \mathrm{C}$ rate $\left(64 \mathrm{~A} \mathrm{~g}^{-1}\right)^{21}$, which means that this composite as anode material of a lithium ion battery could be charged to full capacity in 1.25 minutes. Although the high price of germanium is a drawback for the commercialization of this anode material, the $\mathrm{C}-\mathrm{Ge} / \mathrm{C}$ composite has the potential for being a high-energy and high-power anode material for lithium-ion batteries. 
Hollow-structured $\alpha-\mathrm{Fe}_{2} \mathrm{O}_{3} /$ carbon nanocomposite with a high surface area of around $260 \mathrm{~m}^{2} \mathrm{~g}^{-1}$ (Figure 2), synthesized by a one-step, in situ, and industrially-oriented spray pyrolysis method, showed a high capacity of 1210 mAh $\mathrm{g}^{-1}$ at a current density of $0.1 \mathrm{C}\left(100 \mathrm{~mA} \mathrm{~g}^{-1}\right)$, enhanced rate capability, and excellent cycling stability (720 mAh g ${ }^{-1}$ at a current density of $2 \mathrm{C}$ up to 220 cycles) $)^{22}$. The reasons are (1) the high-surface-area hollow structure composed of thin nanosheets can facilitate the contact between active materials and the electrolyte, and shorten the lithium diffusion length; (2) the well dispersed small $\alpha-\mathrm{Fe}_{2} \mathrm{O}_{3}$ nanocrystals in the amorphous carbon can accommodate the volume changes caused by lithium insertion and de-insertion, and could also enhance the electron transport to/within the $\alpha-\mathrm{Fe}_{2} \mathrm{O}_{3}$ particles or crystals.

A strategy to employ graphene as supporting sheets for loading nanosized $\mathrm{SnO}_{2}$ particles with carbon coating layers ${ }^{23}$ has significantly improved the cycling performance, compared to $\mathrm{SnO}_{2}$ /graphene and $\mathrm{SnO}_{2} /$ carbon, as anode material for lithium ion batteries. This is because the graphene sheets and the carbon coating layer enhance the conductivity and buffer the volume changes of nanosized $\mathrm{SnO}_{2}$ particles. A high capacity of $757 \mathrm{mAh} \mathrm{g}^{-1}$ was retained after 150 cycles at current density of $200 \mathrm{~mA} \mathrm{~g}^{-1}$.

A novel nanocrystalline porous $\alpha-\mathrm{LiFeO}_{2}-\mathrm{C}$ composite with a high surface area of around $115 \mathrm{~m}^{2} \mathrm{~g}^{-1}$ (Figure 3) ${ }^{24}$ delivered a significantly higher reversible capacity and excellent cycling stability (230 $\mathrm{mAh} \mathrm{g}^{-1}$ at $0.5 \mathrm{C}$ after 100 cycles). Even at the high rate of $3 \mathrm{C}$, the electrode showed more than $50 \%$ of the capacity at low rate $(0.1 \mathrm{C})$. The excellent electrochemical performance of this 
nanocomposite electrode is due to the porous conductive architecture among the nanoparticles, which decreases the absolute volume changes and increases the mobility of lithium ions, also offering conductive pathways along the whole interconnected wall in the structure, which is favourable for the transport of electrons, promotes liquid electrolyte diffusion into the bulk materials, and acts as a buffer zone to absorb the volume changes.

$\mathrm{LiFePO}_{4}-\mathrm{Fe}_{2} \mathrm{P}-\mathrm{C}$ composite prepared by a simple ultra-fast solvent assisted manual grinding method, combined with solid state reaction, showed specific capacity of $167 \mathrm{mAh} \mathrm{g}^{-1}$ at $0.2 \mathrm{C}$ and $146 \mathrm{mAh} \mathrm{g}^{-1}$ at $5 \mathrm{C}$ for 100 cycles, respectively. At the high current density of $1700 \mathrm{~mA} \mathrm{~g}^{-1}$ (10 C rate), it exhibited long-term cycling stability, retaining around $96 \%\left(131 \mathrm{mAh} \mathrm{g}^{-1}\right)$ of its original discharge capacity beyond 1000 cycles (Figure 4), which can meet the requirements of a lithium-ion battery for large-scale power applications ${ }^{25}$. The superior high rate performance, and long-term cycling stability of the $\mathrm{LiFePO}_{4-}$ $\mathrm{Fe}_{2} \mathrm{P}-\mathrm{C}$ (5.8 wt.\% C) electrode could be thus explained: (1) nanosizing and carbon coating increase ionic and electronic conductivity; (2) the carbon coating layer maintains the electrode integration and conductivity during volume change; (3) an appropriate carbon content (5.8 wt.\% C) can lead to a more uniform distribution of carbon and $\mathrm{Fe}_{2} \mathrm{P}$ clusters, and also help to create a porous architecture of the materials at the same time; and (4) the carbon, $\mathrm{Fe}_{2} \mathrm{P}$ clusters, and $\mathrm{LiFePO}_{4}$ particles provide multi-dimensional channels for charge transfer and reduce the resistance for lithium ion migration. 
The above excellent electrochemical performance of the nanocomposite electrode is due to the porous conductive architecture among the nanoparticles, which offers only a small absolute volume change. The carbon matrix also offers conductive pathways, which are favourable for the transport of electrons, promotes liquid electrolyte diffusion into the bulk materials, and acts as a buffer zone to absorb the volume changes. So nanomaterials play an important role for lithium rechargeable batteries

\subsection{Functional nanostructured materials for supercapacitors}

Supercapacitors have much longer cycle life, fast charge and higher power density than batteries, but their energy density is still very low making them heavy and bulky. To solve this problem, the research in the world has been focused on two main fronts - (1) combination of pseudocapacitor (metal oxides) and electrical double layer capacitors (carbonaceous materials) materials, and (2) the engineering of new structures and morphologies.

Electrodeposited $\mathrm{MnO}_{2}$ nanowire/carbon nanotube (CNT) paper composite showed specific capacitance as high as $167.5 \mathrm{~F} \mathrm{~g}^{-1}$ at a current density of $77 \mathrm{~mA} \mathrm{~g}^{-1}$. After 3000 cycles, the composite paper can retain more than $88 \%$ of initial capacitance, showing good cyclability ${ }^{26}$. The $\mathrm{MnO}_{2}$ nanowire/CNT paper composite may have great potential for commercial application in totally flexible supercapacitors. The improved electrochemical performance of the composite 
electrode can be explained as (1) the CNT paper is a highly conductive, flexible, and an active substrate for the supercapacitor electrode; and (2) the nanowire structure of the $\mathrm{MnO}_{2}$ facilitates contact between the electrolyte and the active materials, and thus improves the electrode capacitance.

Globular-shaped reduced graphene oxide $-\mathrm{Co}_{3} \mathrm{O}_{4}$ nanocomposite made by the spray pyrolysis method showed a specific capacitance of $687 \mathrm{~F} \mathrm{~g}^{-1}$ at 5 $\mathrm{mV} / \mathrm{s}^{27}$. It is clear that the graphene enhances the electrochemical properties of the nanocomposite by acting as a conductive support that is ideal for electron and ion transportation, while the graphene capsule stabilizes the electrode structure, with good electrical contact between the $\mathrm{Co}_{3} \mathrm{O}_{4}$ particles and the conductive graphene during the charge-discharge process.

Graphene oxide - multi-walled carbon nanotube (MWCNT) composite, MWCNTs, and graphene oxide showed specific capacitances of 251, 85, and 60 F/g at a scan rate of $5 \mathrm{mV} \mathrm{s}^{-1}$, respectively, and a total increase of $120.5 \%$ was recorded over 1000 cycles for the graphene oxide-MWCNT composite at $20 \mathrm{mV}$ $\mathrm{s}^{-1} \cdot{ }^{28}$ MWCNTs act effectively as a spacer and inhibit the restacking of graphene oxide sheets, thus facilitating the diffusion of electrolyte.

From above examples, we can say nanostructured materials increase the capacitance of supercapacitors.

\subsection{Functional nanostructured materials for hydrogen storage}


Hydrogen, when burned, produces only water, which is harmless to the environment, and is an ideal fuel for transportation. For automotive application, the hydrogen storage system must be able to hold enough fuel for a driving range of $450 \mathrm{~km}$ before refilling. At room temperature and atmospheric pressure, $4 \mathrm{~kg}$ of hydrogen occupies a volume of $45 \mathrm{~m}^{3}$. This corresponds to a balloon $5 \mathrm{~m}$ in diameter — hardly a practical solution for a vehicle ${ }^{8}$. Currently, no technology meets this goal within the constraints of allowable weight and volume for passenger cars. For hydrogen as a future energy carrier, the development of an efficient, robust, safe, and inexpensive hydrogen storage system is needed. The United States DOE has established requirements that are to develop and achieve an on-board hydrogen storage system with at least 5.5 wt\% H by 2015. Today's research has been focused on the hydrocarbon materials, conventional hydride ( $\left.\mathrm{LaNi}_{5}\right)$, light metal hydride $\left(\mathrm{MgH}_{2}\right)$ and complexes $\left(\mathrm{LiBH}_{4}, \mathrm{NH}_{3} \mathrm{BH}_{3}\right.$, $\left.\left(\mathrm{NH}_{2} \mathrm{BH}_{2}\right)_{\mathrm{n}}\right)$ hydrides.

A large number of nanostructured carbon materials have been investigated, and the values published for the quantity of hydrogen absorbed in the nanostructured carbon materials vary between 0.4 mass\% and 67 mass\%. Our idea was to create a material with pores that attract hydrogen, making it possible to stuff more hydrogen molecules into a small volume. We have fabricated selfaligned graphene oxide (GO) - MWCNT hybrid frameworks with a high degree of orientation, which demonstrated high hydrogen capacity (up to $2.6 \mathrm{wt} \%$ ) at room temperature ${ }^{29}$. The remarkable synergistic properties from combining GO and MWCNTs in a hybrid structure offer a novel yet simple way of designing 
GO-based hybrid frameworks with extraordinary hydrogen storage capacities by incorporating two different materials, neither one of which alone might be completely perfect for the required application.

Lithium borohydride $\left(\mathrm{LiBH}_{4}\right)$ is commercially available and has extremely high theoretical hydrogen capacity $\left(18.3 \mathrm{wt} \%, 121 \mathrm{~kg} \mathrm{~m}^{-3}\right)$, but its practical application as a hydrogen storage material is limited, due to the high gasevolution temperature (about $380{ }^{\circ} \mathrm{C}$ ). Using copper-metal-organic frameworks (Cu-MOFs) as the template to load $\mathrm{LiBH}_{4}$, the new material, $\mathrm{LiBH}_{4} @ \mathrm{Cu}-\mathrm{MOFs}$ (Figure 5), achieves a much lower dehydrogenation temperature than pristine $\mathrm{LiBH}_{4}{ }^{30}$. The confinement by nanostructured materials and the consequent redox reaction between $\mathrm{LiBH}_{4}$ and $\mathrm{Cu}-\mathrm{O}$ units enable dehydrogenation to occur in $\mathrm{LiBH}_{4} @ \mathrm{Cu}-\mathrm{MOFs}$ at a much lower dehydrogenation temperature than pristine $\mathrm{LiBH}_{4}$. Such nanoconfinement could be widely used in cooperation with other positive effects, such as redox, catalysis, or hydrolysis reactions, to achieve the potential for hydrogen storage materials with vastly improved dehydrogenation.

Above a few examples show nanostructure improves the hydrogenation/dehydrogenation of hydrogen storage materials.

\subsection{Functional nanostructured materials for fuel cells}

Molten carbonate fuel cell (MCFC) and solid oxide fuel cell (SOFC) need to be operated at high operation temperature $\left(>500{ }^{\circ} \mathrm{C}\right)$. Proton exchange membrane fuel cell (PEMFC) and direct methanol fuel cell (DMFC) can only be operated at low temperature $\left(<80{ }^{\circ} \mathrm{C}\right)$, DMFCs show lower power density and low 
methanol utilization efficiency: $<50 \%$. Alkaline fuel cell (AFC) having the electrode with cheap catalyst $(\mathrm{Ni}, \mathrm{Cu}$, Co etc.) instead of Pt can be operated at ambient temperature, and even at low temperature, potential portable and onboard power source, but alkaline solution $(\mathrm{NaOH}, \mathrm{KOH})$ easily react with $\mathrm{C}$ in fuel, also electrolyte and electrode are deteriorated by formation of carbonate, and needs purer $\mathrm{H}$ gas as fuel. The current research target is to get high energy density and high utilization efficiency by new catalysts with high catalytic activity and low cost.

$\mathrm{Pt}_{1-\mathrm{x}} \mathrm{Co}_{\mathrm{x}}$ alloy nanoparticles could be promising cathode catalysts for oxygen reduction in PEM fuel cells, with the feature of much reduced cost, but significantly increased oxygen reduction. $\mathrm{Pt}_{0.55} \mathrm{Co}_{0.45}$ catalyst ${ }^{31}$ exhibits the highest electrochemical reactivity. The as-prepared catalysts have a uniform distribution on the carbon matrix, with an average particle size of less than $10 \mathrm{~nm}$ (Figure 6). Electrochemical testing results indicate that the presence of Co significantly enhances the electrocatalytic activity and long-term stability of the catalysts.

The Pt/Sn/PMo ${ }_{12} / \mathrm{CNT}$ catalyst ${ }^{32}$ exhibited the lowest onset potential for electro-oxidation of adsorbed $\mathrm{C}$ intermediates, compared to the $\mathrm{Pt} / \mathrm{Sn} / \mathrm{CNT}$ and Pt/CNT catalysts. It also generated much higher current density for methanol oxidation at room temperature compared to the $\mathrm{Pt} / \mathrm{Sn} / \mathrm{CNT}$ and $\mathrm{Pt} / \mathrm{CNT}$ catalysts, which were prepared by the same method.

Using $\mathrm{WO}_{3}$ to modify the conventional $\mathrm{Pt} / \mathrm{C}$ catalyst, $\mathrm{Pt}_{x}-\mathrm{WO}_{3} / \mathrm{C}$ electrocatalysts $^{33}$ showed higher catalytic activity towards ethanol electro- 
oxidation than the commercial Pt/C catalysts. This could be attributed to the role of $\mathrm{WO}_{3}$ in promoting the oxidative removal of the adsorbed intermediate species of ethanol oxidation. As is well-known, the high activity and stability of Pt metal, especially in an acidic environment, makes it a suitable electrocatalyst for electrooxidation of many small chemical molecules. Pure platinum is not a very good anode catalyst for ethanol or methanol electro-oxidation at room or moderate temperature, however, because it is readily poisoned by the strongly adsorbed intermediates, such as $\mathrm{CO}_{\mathrm{ads}}$ (one of the main poisoning species).

The few examples above indicate that nanomaterials enhance the electrocatalytic activity of the catalysis in fuel cells.

\section{Summary}

Functional nanostructured materials can play a significant role in improving the electrochemical performance of proposed alternative electrode materials. They are promising for clean energy applications such as lithium ion batteries, supercapacitors, hydrogen storage, fuel cells, and other applications due to their specific nanostructures and outstanding properties.

\section{Acknowledgments}

The author would like to thank Dr. Tania Silver for critical reading and also gratefully acknowledges financial support from Australian Research Council Discovery and Linkage Projects, and the Centre of Excellence for Electromaterials Science. Thanks are also due to S.X. Dou, Z.P. Guo, X. Yu, J. 
Mao, Z. Huang, G. Wang, J.Z. Wang, K. Konstantinov, S.L. Chou, S.H. Ng, M.S.

Park, M.M. Rahman, K. Seng, C. Zhang, A. Chidembo, S. Aboutalebi, H. Wu, D.M. Han, and D. Zhang.

\section{References}

1. J. B. Goodenough, Y. Kim, Chem. Mater. 22, 587 (2010).

2. B. L. Ellis, K. T. Lee, L. F. Nazar, J. Mater. Chem. 22 (3), 591 (2010)

3. B. Scrosati, J. Garche, J. Power Sources, 195, 2419 (2010)

4. Y. Wang, G. Cao, Adv. Mater., 2008, 20, 2251 (2008)

5. Hong Li, Zhaoxiang Wang, Liquan Chen, and Xuejie Huang, Adv. Mater., 21, 4593 (2009)

6. J. Chen, F. Cheng, Accounts of Chemical Research, 42(6), 713 (2009)

7. M. Jayalakshmi, K. Balasubramanian, Int. J. Electrochem. Sci., 3, 1196 (2008)

8. L. Schlapbach, A. Züttel, Nature, 414, 353 (2001)

9. A. Züttel, P. Sudan, Ph. Mauron, T. Kiyobayashi, Ch. Emmenegger, L. Schlapbach, Int. J. Hydrogen Energy, 27, 203 (2002)

10. B. C. H. Steele, A. Heinzel, Nature, 414, 345 (2001) 
11. S. H. Ng, J. Wang, D. Wexler, K. Konstantinov, Z. P. Guo, H. K. Liu, Angew. Chem., Int. Ed., 45, 6896 (2006)

12. M. S. Park, G. X. Wang, Y. M. Kang, D. Wexler, S. X. Dou, H. K. Liu, Angew. Chem., Int. Ed. 46 (5), 750-753, (2007)

13. H. K. Liu, G. X. Wang, Z. Guo, J. Wang, K. Konstantinov, J. Nanosci. Nanotechnol., 6, 1-15 (2006)

14. H. K. Liu, G. X. Wang, Z. P. Guo, J. Z. Wang, K. Konstantinov, J. New Mater. Electrochem. Systems, 10, 101-104 (2007)

15. H. K. Liu, Z. P. Guo, J. Z. Wang, K. Konstantinov, J. Mater. Chem., 20(45), 10055 (2010)

16. F. Cheng, Z. Tao, J. Liang, J. Chen, Chem. Mater., 20, 667 (2008)

17. Brian L. Ellis, Kyu Tae Lee, Linda F. Nazar, Chem. Mater., 22, 691-714 (2010)

18. G. R. Patzke, F. Krumeich, R. Nesper, Angew. Chem., Int. Ed., 41, 2446 (2002)

19. M. Winter, R. J. Brodd, Chem. Rev., 104, 4245 (2004) 
20. S. L. Chou, J. Z. Wang, M. Choucair, H. K. Liu, J. A. Stride, S. X. Dou, Electrochemistry Communications, 12(2), 303 (2010)

21. K. Seng, M. Park, Z. Guo, Z., H. K. Liu, J. Cho, Angew. Chem., Int. Ed., 51(23), 5657 (2012)

22. S. L. Chou, J. Z. Wang, D. Wexler, K. Konstantinov, C. Zhong, H. K. Liu, S. X. Dou, J. Mater. Chem., 20(11), 2092 (2010)

23. C. Zhang, X. Peng, Z. Guo, C. Cai, Z. Chen, D. Wexler, S. Li, H. K. Liu, Carbon, 50, 1897 (2012)

24. M. M. Rahman, J. Wang, Z. Chen, H. K. Liu, Energy \& Environ. Sci., 4(3) 952 (2011)

25. M. Rahman, J. Z. Wang, R. Zeng, D. Wexler, H. K. Liu, J. Power Sources, 206, 259-266 (2012)

26. S. L. Chou, J. Z. Wang, S. Y. Chew, H. K. Liu, S. X. Dou, Electrochem. Commun., 10, 1724 (2008)

27. A. Chidembo, S.H. Aboutalebi, .K. Konstantinov, M. Salari, B. Winton, S. A. Yamini, I. P. Nevirkovets, H. K. Liu, Energy \& Environ. Sci., 5, 5236 (2012)

28. S. Aboutalebi, A. Chidembo, M. Salari, K. Konstantinov, D. Wexler, H. K. Liu, S. X. Dou, Energy \& Environ. Sci., 4(5), 1855 (2011) 
29. S. H. Aboutalebi , S. Aminorroaya-Yamini , I. Nevirkovets, K. Konstantinov, H. K. Liu, Adv. Energy Mater., DOI: 10.1002/aenm.201200154 (2012)

30. W. Sun, S. Li, J. Mao, Z. Guo, H. K. Liu, S. X. Dou, X. Yu, Dalton Trans., 40, 5673 (2011)

31. H. Wu, D. Wexler, H. K. Liu, O. Savadogo, J. Ahn, G. Wang, Mater. Chem. Phys., 124, 841-844 (2010)

32. D. M. Han, Z. P. Guo, R. Zeng, C. J. Kim, Y. Z. Meng, H. K. Liu, Int. J. Hydrogen Energy, 34, 2426-2434 (2009)

33. D. Zhang, Z. Ma, G. Wang, K. Konstantinov, X. Yuan, H. K. Liu, Electrochem. Solid-State Letters, 9(9) A423-A426 (2006)

\section{Figure Captions}

Figure 1. TEM images showing the formation of germanium/carbon nanostructures from the germanium oxide precursors: a) $\mathrm{GeO}_{2}$ nanoparticles, b) carbon-coated $\mathrm{GeO}_{2}$ nanoparticles, c) C-Ge/C. The black arrows in (b,c) indicate that the carbon shells have a thickness of about $3 \mathrm{~nm}$. Adopted from Reference 21. 
Figure 2. Typical SEM (a, b), TEM (c, d) and HRTEM (e, f) images of Hollowstructured $\alpha-\mathrm{Fe}_{2} \mathrm{O}_{3} /$ carbon nanocomposite (a, c and e) and hollow-structured $\alpha$ $\mathrm{Fe}_{2} \mathrm{O}_{3}$ (b, d and f). Inset of (c) and (d) are the SAED patterns. Adopted from Reference 26.

Figure 3. (a) TEM image with its corresponding SAED pattern (inset), and (b) HRTEM image of the $\alpha-\mathrm{LiFeO}_{2}$ sample; (c) TEM and (d) HRTEM images of the $\alpha-\mathrm{LiFeO}_{2}-\mathrm{C}$ sample. Adopted from Reference 24 .

Figure 4. Short-term cycle life performance (a), long-term cycle life performance beyond 1000 cycles at $10 \mathrm{C}$ for the $\mathrm{LiFePO}_{4}-\mathrm{Fe}_{2} \mathrm{P}-\mathrm{C}$ electrode (b), the $100^{\text {th }}$ cycle galvanostatic charge-discharge profiles at different current densities from 0.2 to $10 \mathrm{C}$ between 4.3 and $2.5 \mathrm{~V}$ for $\mathrm{LiFePO}_{4}-\mathrm{Fe}_{2} \mathrm{P}-\mathrm{C}$ (1) electrode (c), cyclic voltammogram of $\mathrm{LiFePO}_{4}-\mathrm{Fe}_{2} \mathrm{P}-\mathrm{C}$ electrode at a scan rate of $0.1 \mathrm{mV} \mathrm{s}^{-1}$ (d), and electrochemical impedance spectra of the bare- $\mathrm{LiFePO}_{4}$ and $\mathrm{LiFePO}_{4}-\mathrm{Fe}_{2} \mathrm{P}-\mathrm{C}$ electrodes, and the equivalent circuit (inset) (e). Adopted from Reference 25.

Figure 5. Schematic diagram of $\mathrm{LiBH}_{4}$ molecules loaded into the pores of $\mathrm{Cu}$ MOFs. (The interaction between the $\mathrm{LiBH}_{4}$ and the $\mathrm{Cu}^{2+}$ ions is indicated by the dotted lines.) Adopted from Reference 30. 
Figure 6. Bright-field TEM images of $\mathrm{Pt}_{1-\mathrm{x}} \mathrm{Co}_{\mathrm{x}} / \mathrm{carbon}$ catalysts: (a) $\mathrm{Pt}_{0.8} \mathrm{Co}_{0.2} /$ carbon; (b) $\mathrm{Pt}_{0.55} \mathrm{Co}_{0.45} /$ carbon; (c) Pt/carbon. Adopted from Reference 31.

Author biography: Prof. Hua Kun Liu has been a co-ordinator of the energy materials research program at the Institute for Superconducting and Electronic Materials, the University of Wollongong since 1995. She was awarded ARC Senior Research Fellowship (1994-1999), Australian Professorial Fellowship (APF) (1999-2003), APF within ARC Centre for Nanostructured Electromaterilas (2003-2005) and APF within ARC Centre for Electromaterials Science (20062010). Her research focuses on lithium rechargeable batteries, supercapacitors, fuel cells and hydrogen storage materials. 

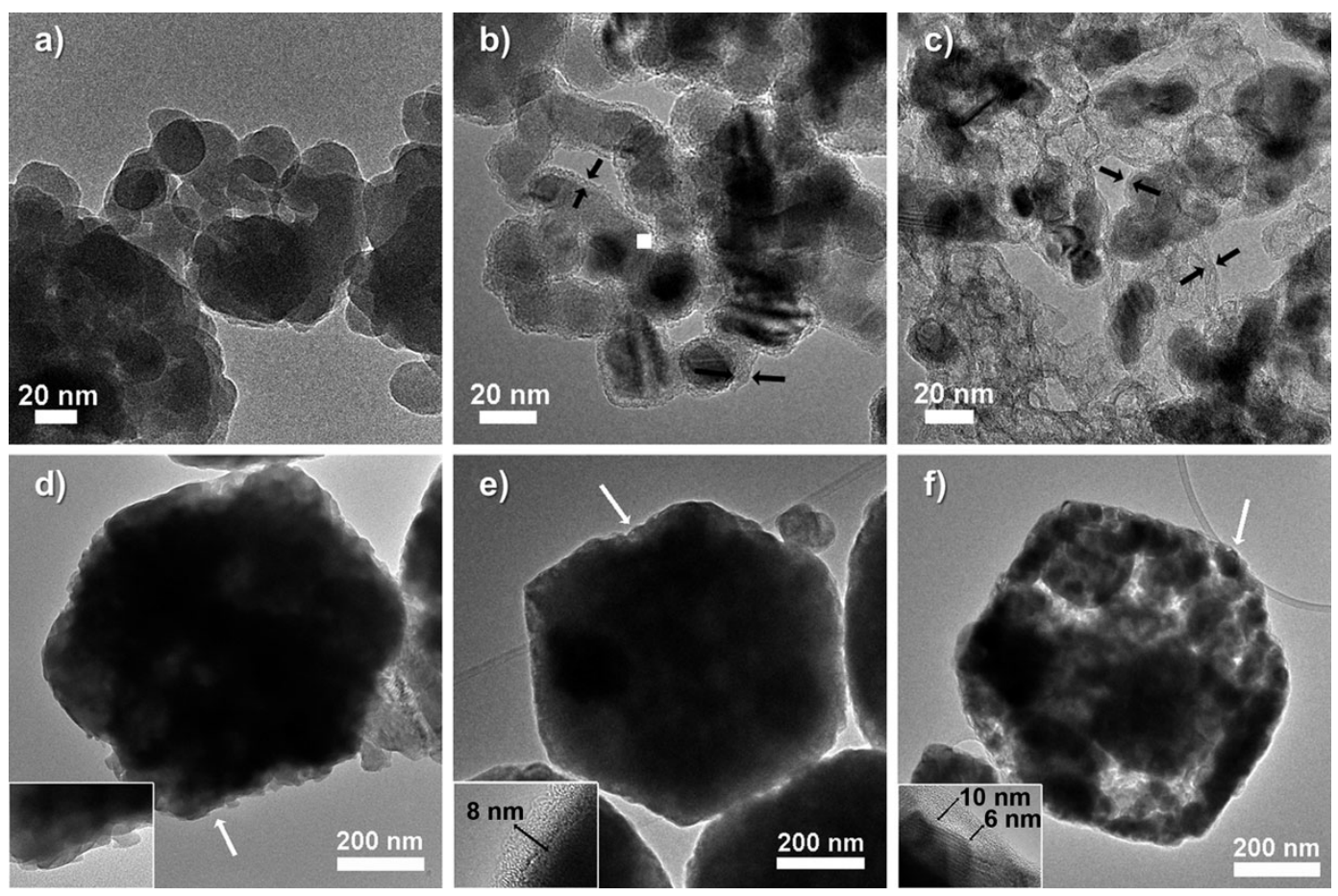

Figure 1. 

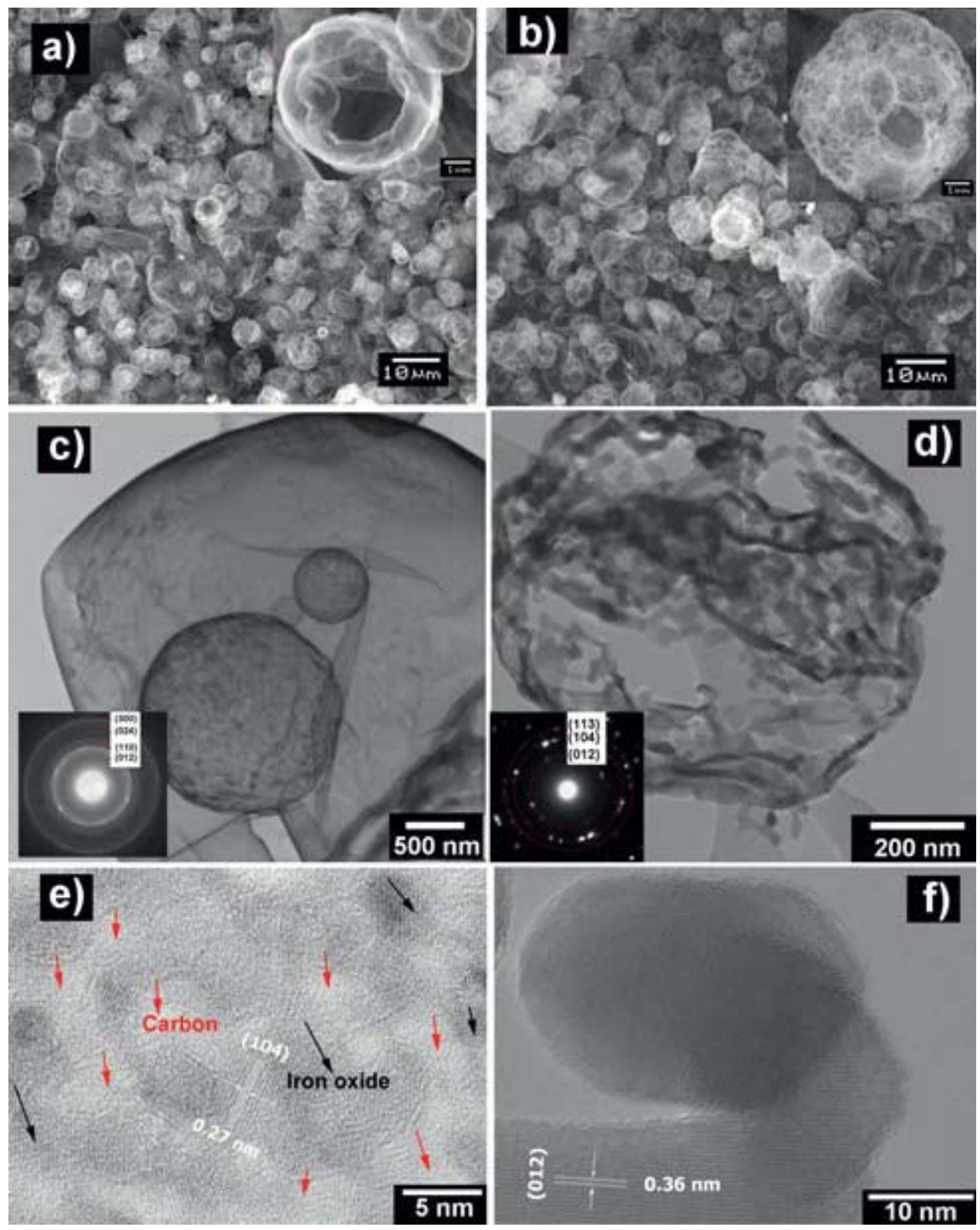

Figure 2. 

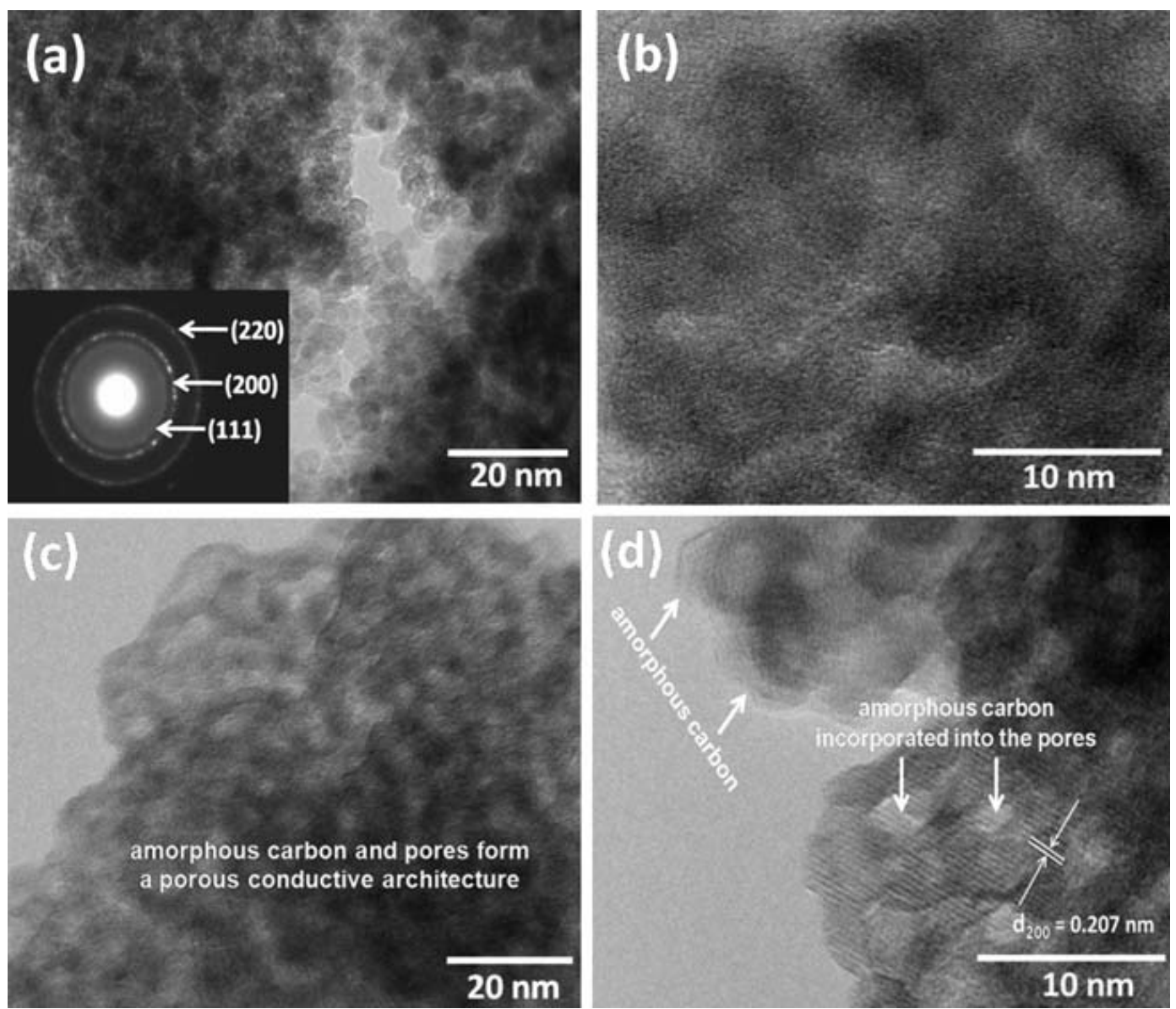

Figure 3. 

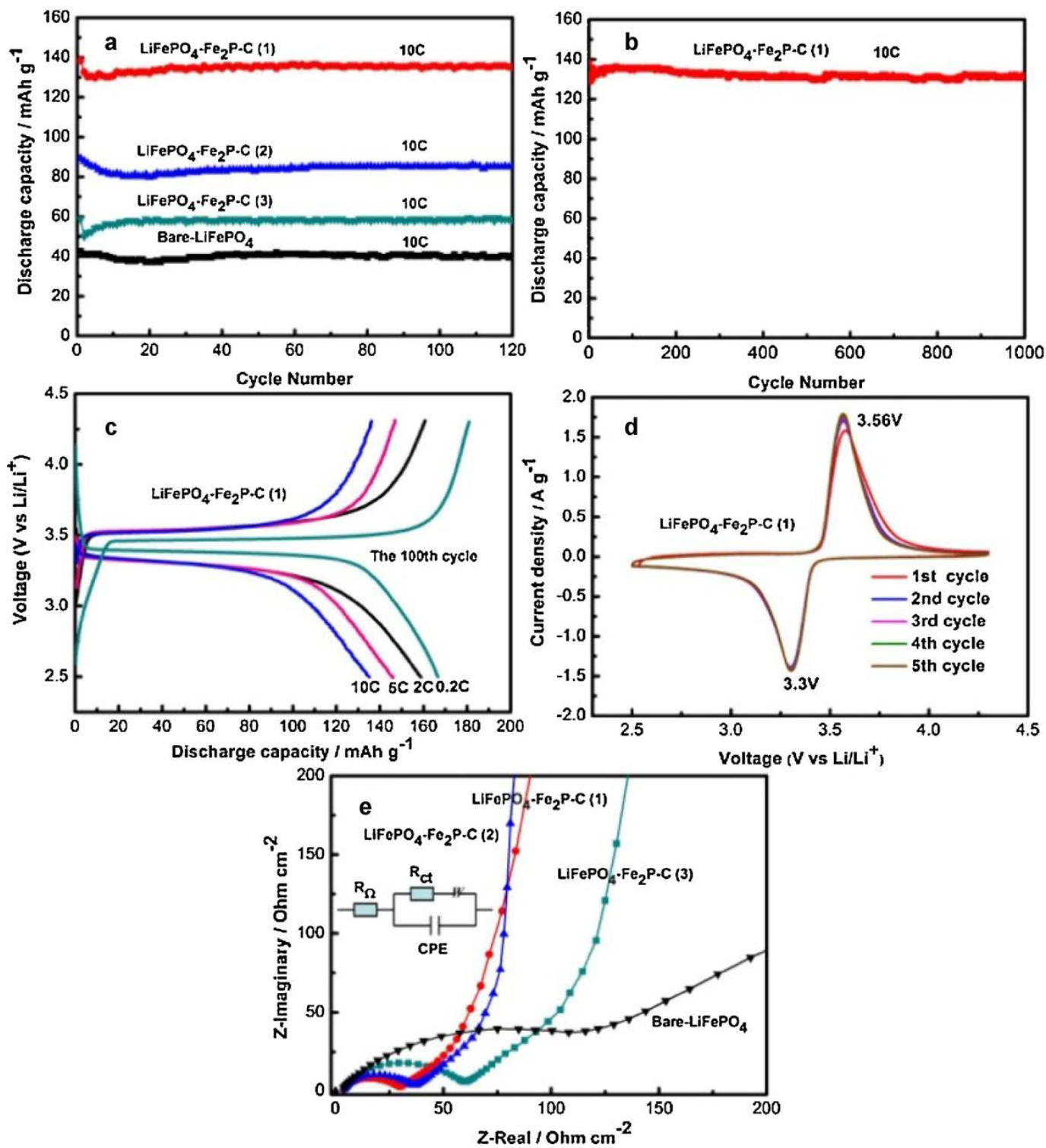

Figure 4. 


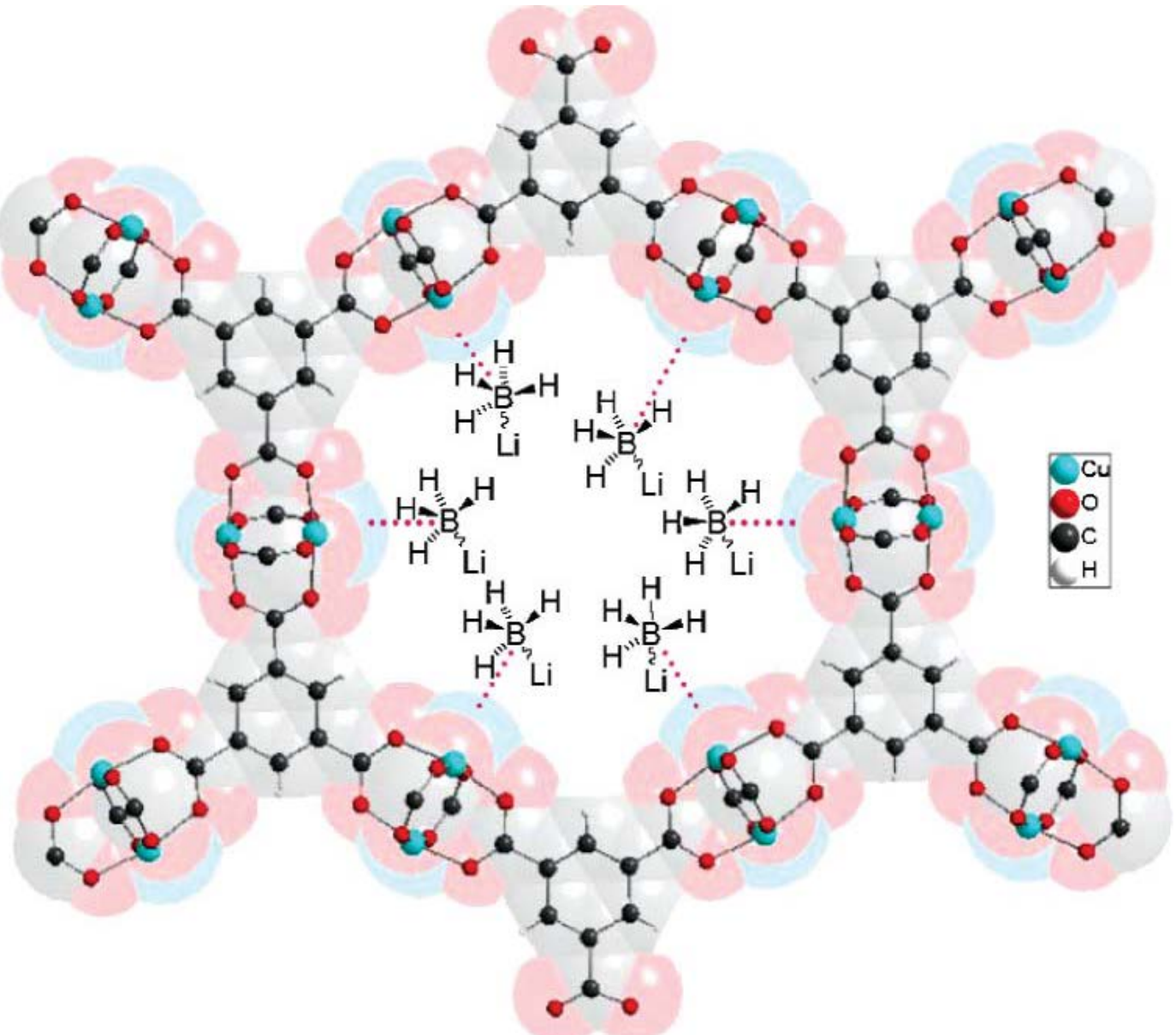

Figure 5. 

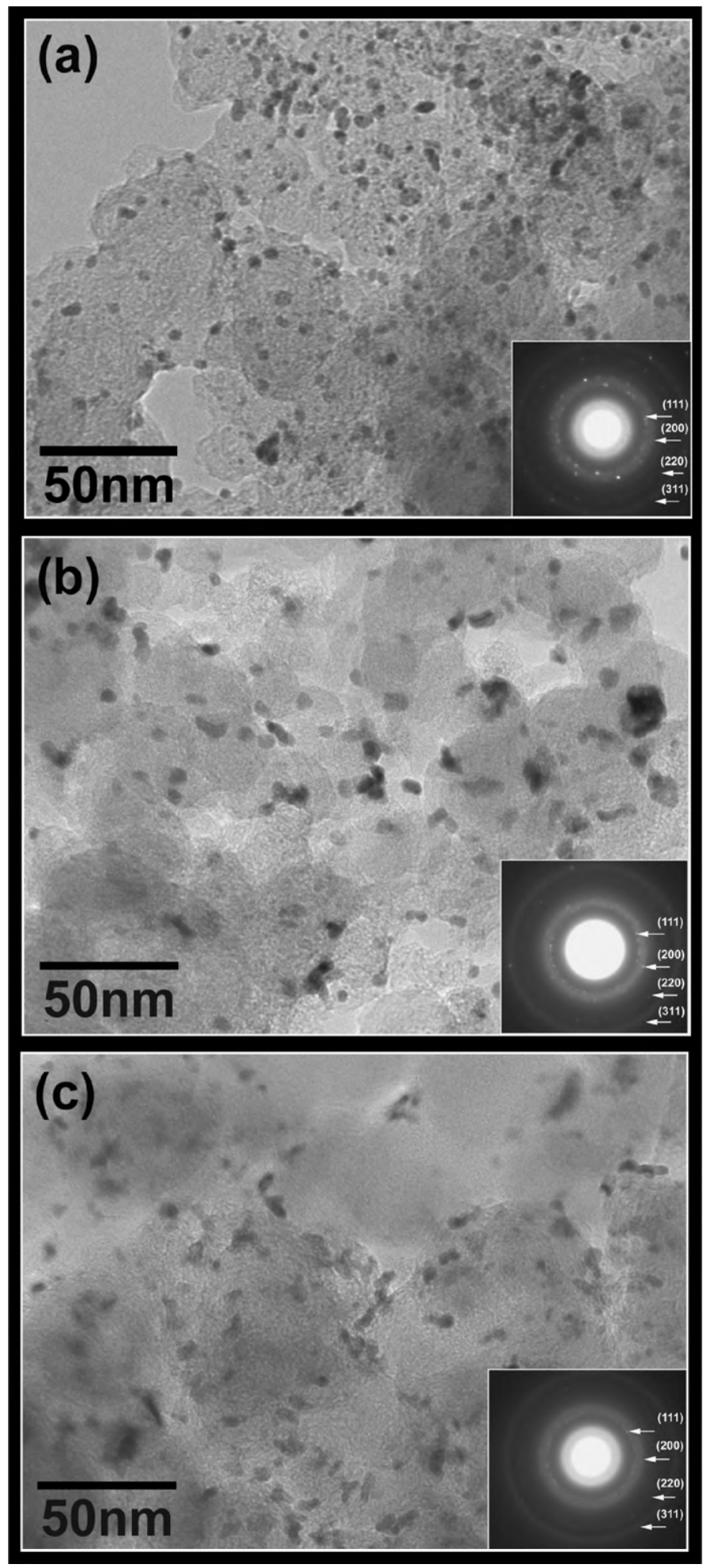

Figure 6. 